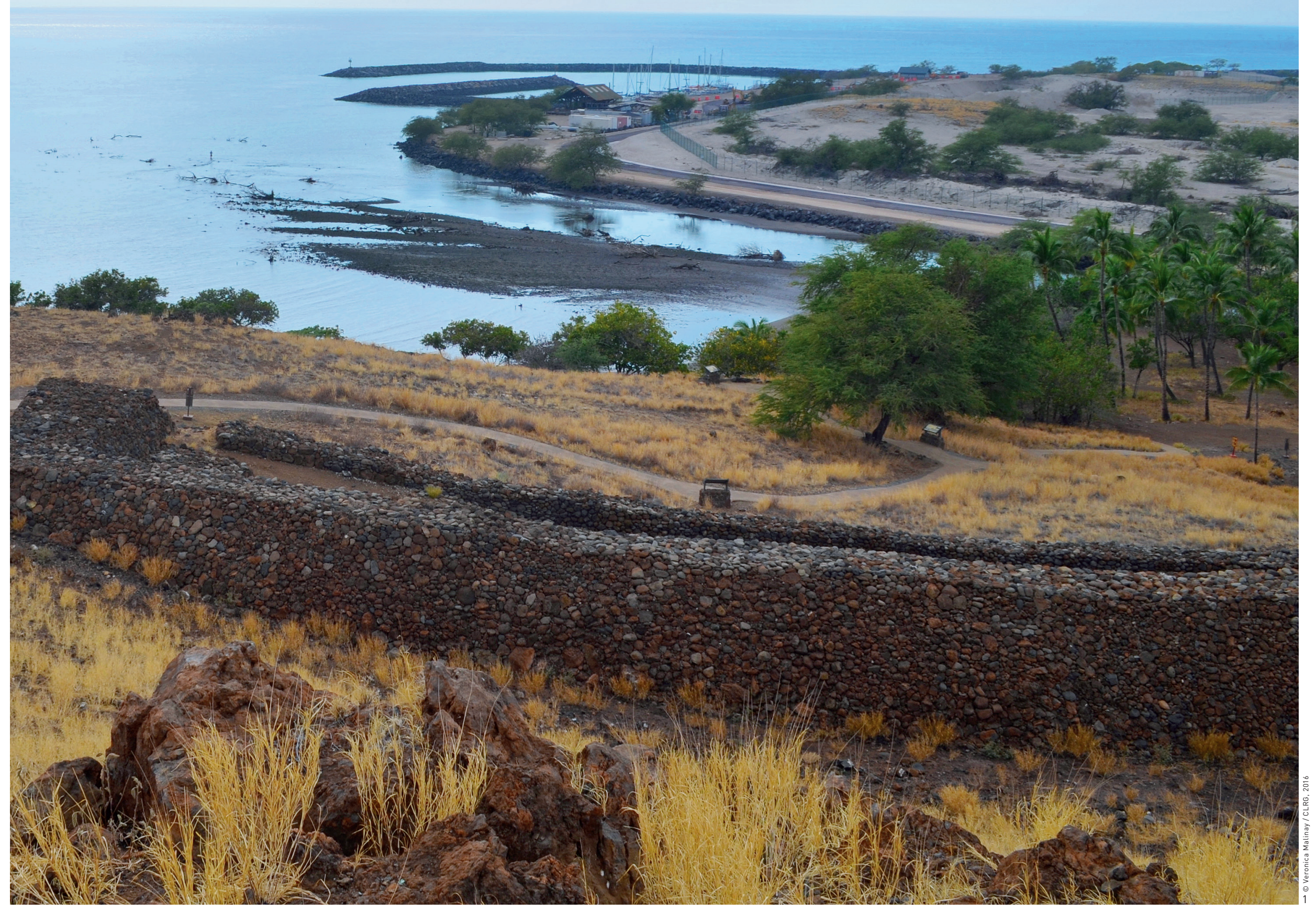




\section{气候变化对文化景观之影响: 以美国太平洋沿岸地区国家公园为例 CLIMATE CHANGE IMPACTS ON CULTURAL LANDSCAPES: A PRELIMINARY ANALYSIS IN U.S. NATIONAL PARKS ACROSS THE PACIFIC WEST}

罗伯特 · Z 梅尔尼克, 诺亚 $\cdot$ P . 克尔 / Robert Z. MELNICK*, Noah P. KERR *Department of Landscape Architecture, University of Oregon, 1585 E I3th Ave, Eugene, Oregon, 97403, USA rzm@uoregon.edu 公园管理局于1956年颁 布的一项十年计划, 旨 在到公园管理局成立 50 周年之际 (1966年) , 实现游客服务水平的大 幅提升。

从普乌科侯拉神庙国家 历史遗址向西远洮位于 夏威夷西海岸的佩勒肯 恩海湾。预测的海平面 变化将会对沿海地区 (包括具有文化价值的 椰树林）造成威胁。

View west from Pu'ukohola Heiau National Historical Site, (n) overlooking Pelekane coast. Projected change coast. Projected change in sea level poses hazards for the coasta site, including the culturally significant grove of coconut palms.
引言

在过去的半个世纪中，美国国家公园系 统 (NPS) 在其文化资源遗产推广方面取得 了显著成果。其中, 文化景观名录 $(C L I)$ 体 系的贡献尤为突出 ${ }^{[1][2]}$ 。自20世纪60年代以 来, 随着 “66计划” ${ }^{1}$ 的不断推进、《历史 场所报告》的发布, 以及1968年对历史遗迹 的官方认证, 文化景观的重要价值得到了越 来越多的关注和认可 ${ }^{[3]-[5]}$ 。20世纪 80 年代初 期, 《文化景观: 国家公园中的乡村历史古 迹》等技术指南相继推出, 这一新兴的资源 管理领域让人们深深地意识到, 人类与自然 这两种截然不同的力量紧密交织并在大地之 上留下了深刻的文化印迹 ${ }^{[6]}$ 。与此同时, 这 些文化印迹也塑造了文化景观的历史特征, 正如卢多米尔 · 龙齐所强调的, 它们赋予了 人们同时享受自然与文化熏陶的机会 ${ }^{[7]}$ 。直 至今日, 这种交织关系仍指导着NPS的管理 实践, 以激发公园所在地的文化景观所固有 的生命活力和文化活力。此外, 由于此种关
系的存在, 文化景观的独特性也在不断发生 变化, 虽然这种变化有时并不如人所愿。例 如, 一些存在已久的植物正濒临灭绝, 雨水 和暴风不断侵蚀土地……因此, 有效的资源 管理不仅要适应某一尺度下的气候变化, 更应 当在多重尺度上管理, 甚至减缓这些变化。

如今, 气候变化为我们认识和保护文化 景观带来了更多的不确定性。那么, 如何利 用这些不断变化的自然或人为因素, 提高现 有景观保护措施（例如那些用于文化景观状 态定期评估的方法）的功效? 对功效这一目 标的追求或许始终都在变化, 且永无止境。 未来, 人们所熟知的气候现象和极端事件将 出现新的变化（如气温和降水量变化），而 这种变化的不确定性会引发人们长期的惶 恐。例如, 海平面上升已对位于沿海地区的 夏威夷州普乌科侯拉神庙国家历史遗址产生 了潜在的气候威胁。此外, 在众多其他气候 威胁中, 森林野火愈发频繁肆虐, 约塞米蒂 国家公园和华盛顿奇兰湖国家游熄区等都曾 遭到过野火的侵害。
摘要

本文阐述了俄勒冈大学文化景观研究小组的一项研究, 分 析了关键气候变量可能对美国国家公园系统中太平洋沿岸地区 文化景观造成的影响。本研究旨在在气候变化的背景下确保国 家公园系统文化景观弹性, 并为未来的相关研究提供借鉴。 关键词

文化景观；气候变化；国家公园；全球性问题；风险；脆弱性

\section{ABSTRACT}

The study of climate change impacts on cultural landscapes in the Pacific West Region of the National Park System by the University of Oregon's Cultural Landscape Research Group, assessed how these landscapes might be affected by key climate variables, and developed recommendations for future research toward the agency's goal of ensuring cultural landscapes' resilience in light of climate change variables.

KEY WORDS

Cultural Landscapes; Climate Change; National Parks; Global Issue; Exposure; Vulnerability

整理 王颖

译 张健

EDITED BY Ying WANG

TRANSLATED BY Angus ZHANG 


\section{项目地址}

美国太平洋沿岸地区国家公园

项目委托:

美国国家公园管理局

项目负责人:

Robert Z. Melnick

项目团队:

Noah P. Kerr、 Veronica Malinay、 Alison Lewis.

Nadja Quiroz

设计时间:

2016 2017年

所获奖项:

2017年美国景观设计师协会研究类荣誉奖

\section{LOCATION:}

National Parks, Pacific West Region, USA

CLIENT:

US National Park Service

PROJECT LEADER:

Robert Z. Melnick

PROJECT TEAM:

Noah P. Kerr, Veronica Malinay, Alison Lewis, Nadja

Quiroz

RESEARCH PERIOD

2016 2017

AWARD:

2017 ASLA Honor Award in Research Category

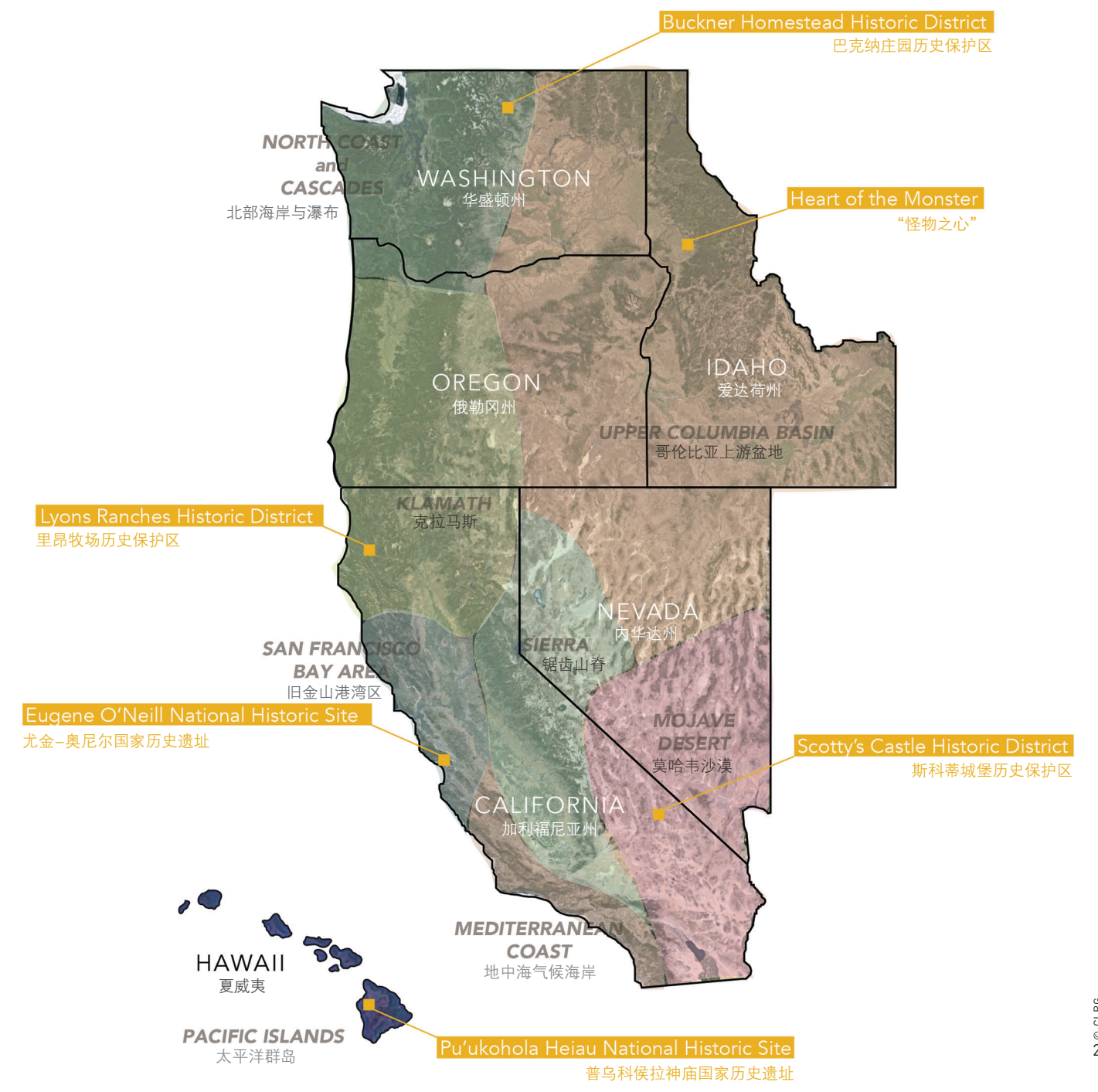

究其本质, 正视其不确定性是应对气候 变化的重中之重。而对于那些拥有丰富土地 类型和网络的地区一一例如太平洋沿岸地区 的国家公园体系一一而言尤其如此。严重的 气候事件往往会带来深远的社会影响, 并引 发人们对此类事件的关注。以近年来的死亡 谷国家公园降雨事件为例，2015年10月18 日，对流性降雨导致葡萄藤峡谷暴发了严重 的山洪。两天之内, 整个地区的降雨量即已 达到以往的年平均降雨量, 远远超过了百年 一遇洪水事件的级别 ${ }^{[8][9]}$ 。其间, 洪水径流量 超过了 $85 \mathrm{~m}^{3} / \mathrm{s}$, 对死亡谷历史遗址斯科蒂城 堡造成了严重破坏。为有效预测此类可能更
为频繁的、对更大范围内的文化景观有着重 大破坏影响的极端事件, 公园管理者应考虑运 用能够明确场地基本情况的系统性方法 ${ }^{[10]}$ 。

\section{文化景观名录和气候变化适应策略}

CLI是经官方认证的、收录了NPS中所 有重要景观的数据库, 其对每一处特定文化 景观的历史和现状都进行了评估, 包括人类 已知的由历史变迁带来的影响。本文所记录 的研究涵盖了各个文化景观的整体状况及已 有记录的历史影响, 且均依据当前气候变化 的预测数据进行了深入分析。整个过程在CLI 的气候变化影响。通过与NPS的合作, 研究 团队完善了NPS最新的文化资源气候变化响 应框架 ${ }^{[11][12]}$, 以明确预测气候变化将会对美国 西部地区和太平洋岛屿之上的文化景观产生 何种影响。

由此, 俄勒冈大学文化景观研究小组 ( CLRG) 与太平洋沿岸地区的工作人员紧 密协作, 完成了历时两年的研究。该研究分 为两个阶段: 首先, 在气候科学家和其他景 观专业人员的协助下, 研究小组将局地 (即 郡县级) 预测报告进行了汇总, 以评估区域 内记录在册的文化景观与特定气候变量之间
的现有管理框架下进行, 旨在识别并量化预测
2. 案例研究所选择的6处文化 景观代表了美国太平洋沿 岸地区具有不同景观类型 及区域分布特征的网络。

3. “气候变化与文化景观: 研究、规划与管理”决策 树成为了项目现阶段的工 作指南。

2. The six cultural landscapes case studies represent the Pacific West Region networks, different landscape types, and regional distribution.

3. The decision tree of "Climate Change and Cultural Landscapes: Research, Planning, and Stewardship" guides the current effort for this project. 
的关系; 由此生成的基础模型涵盖了该地区 164处文化景观的所有典型性特征和已有记 录的气候影响。这些历史文化景观场所全部 达到了CLI的认证要求。

基础模型的提出也促进了分析性模型的 初步开发。在分析性模型的帮助下, 文化景 观的脆弱性被量化为随单个景观特征而变化 的函数。根据几种已知的环境灾害和主要的 气候变化预测结果, 研究以综合评分的方式 展现出每处文化景观所面临的风险, 这一评 分也可在未来用于比对场地当前的风险和预 测的气候变化可能对其造成的危害。项目选 定了6个场地作为研究案例, 并借此从气候 变化的角度更新我们对于文化景观现状的认 知一一或者说, 这6个场地为我们提供了了解 地面真实情况的机会。项目团队对其中三个 场地进行了回访, 以验证对于场地脆弱性的 初步评估。总体而言, 本研究旨在在气候变 化的背景下确保美国国家公园系统文化景观 弹性, 并为未来的相关研究提供借鉴。

\section{研究场地选择}

项目中的6个案例研究场地主要依据以下 三个选择标准：1）在太平洋沿岸地区的每个 网络中选择一个案例研究场地 (每个网络大致 对应一个生态区域）；2）应涵盖所有经NPS 认定的文化景观类型（如历史遗址、地方特 色景观、人工设计类景观、民族志类景观 等）；3）公园的工作人员能够参与并协助进 行实地调查和研究。最终, 加利福尼亚州红 杉树国家公园里昂牧场、加利福尼亚州死亡 谷国家公园斯科蒂城堡、加利福尼亚州尤金奥尼尔国家历史遗址、华盛顿州北瀑布国家 公园巴克纳庄园、夏威夷州普乌科侯拉神庙 国家历史遗址，以及爱达荷州内兹珀斯国家历 史公园“怪物之心”被选定为案例研究场地。

\section{项目目标}

本研究的目标可概括为 4 个方面: 1) 收 集并整理太平洋沿岸地区43个公园内164处 文化景观的气候变化预测数据, 包括气温、

\section{CLIMATE CHANGE AND CULTURAL LANDSCAPES} 气候变化与文化景观

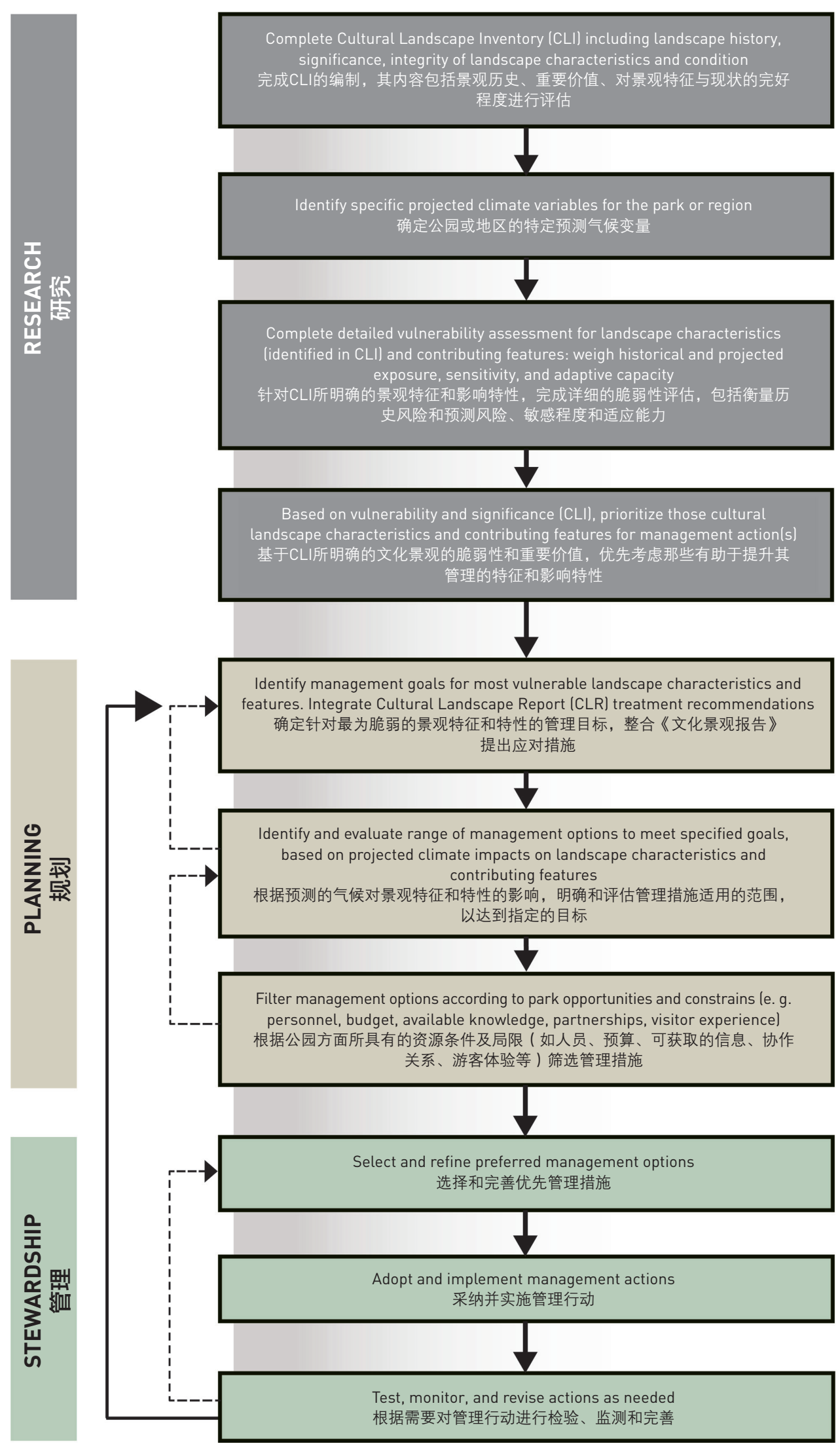


降水、海平面, 以及其他多个方面的变化趋 势；2）明确与这164个文化景观相关的气 候变化潜在风险；3）开展针对6个案例的研 究, 评估选定的文化景观的当前状况及所受 影响, 并制定应对这些影响的措施, 从而提 升这些景观应对灾害的弹性；4）（在第一阶 段中) 对其中的三个案例进行深度分析, 初 步评估文化景观在已知和预测的气候变量影 响下的脆弱性。

\section{研究方法}

本研究以一种全新的文化景观形式, 对 现有的气候变化影响管理框架进行了测试和 完善。适用于每一块场地中的用以表示气候 变量之下文化景观脆弱性的基本公式如下:

（风险 + 敏感程度）/适应能力 $=$ 脆弱性 ${ }^{[13]}$

\section{气候预测}

由于并非所有场地数据都对研究有所 帮助, 研究小组对数据进行了详细分析, 以 预测温度、降水量和海平面等方面的气候
变化趋势。研究所采纳的数据来源于大量 经同行评议的区域气候预测结果, 且参照 了政府间气候变化专门委员会 (IPCC) 提 出的代表性浓度路径 (RCP) 的高排放场景 ( RCP 8.5$)^{[14]-[17] 。}$

\section{灾害风险}

基于地理信息系统（GIS）的分析，本 研究评估了预测的气候变化结果可能会带来 的相关危害。数据来源包括由美国国家海洋 与大气管理局 (NOAA)、美国地质勘探局 (USGS) 和美国林务局 (USFS) 等联邦 机构发布的干旱、火灾、洪水和山体滑坡等 风险的数据。

\section{影响}

在CLI现有的条件式评估体系的基础上， 项目团队就可能引发特定文化景观灾害风险 的影响因素进行了分析, 包括生态环境破 坏、植物物种的减少、侵蚀、暴露于恶劣天 气下的可能、对危害的忽视、病虫害、人工 修剪、对生物演替的影响、结构性损坏、气
温上升/极端高温、均温上升, 以及植被入侵 情况等。所有这些影响都在NPS的追踪记录 范围内。在案例研究的过程中, 团队也对每 一种影响因素进行了实地验证和记录。

\section{结果分析}

2016年, 在项目的第一阶段, 研究团队 建立了一个旨在对脆弱性进行评估的框架, 以揭示文化景观特征可能面临的风险。根据 公开发布的气候变化预测数据, 风险的对象 即 “处于可能受到不利影响的地方和环境中 的人员、生计、物种或生态系统、环境功 能、环境服务、环境资源、基础设施, 以及 经济、社会或文化资产”（参见IPCC 2014 年报告) ${ }^{[18]}$ 。我们对这种解读进行了更新, 进而分析气候变化如何对文化景观特征产生 不利影响。该框架汇总了大量的数据, 并对 之进行了评分, 除气候研究和模型之外, 还 包括实地细节和地理空间分析。脆弱性评估 框架旨在协助NPS 的决策层进行深入研究、 现场评估, 并提出应对方案。该基础模型从
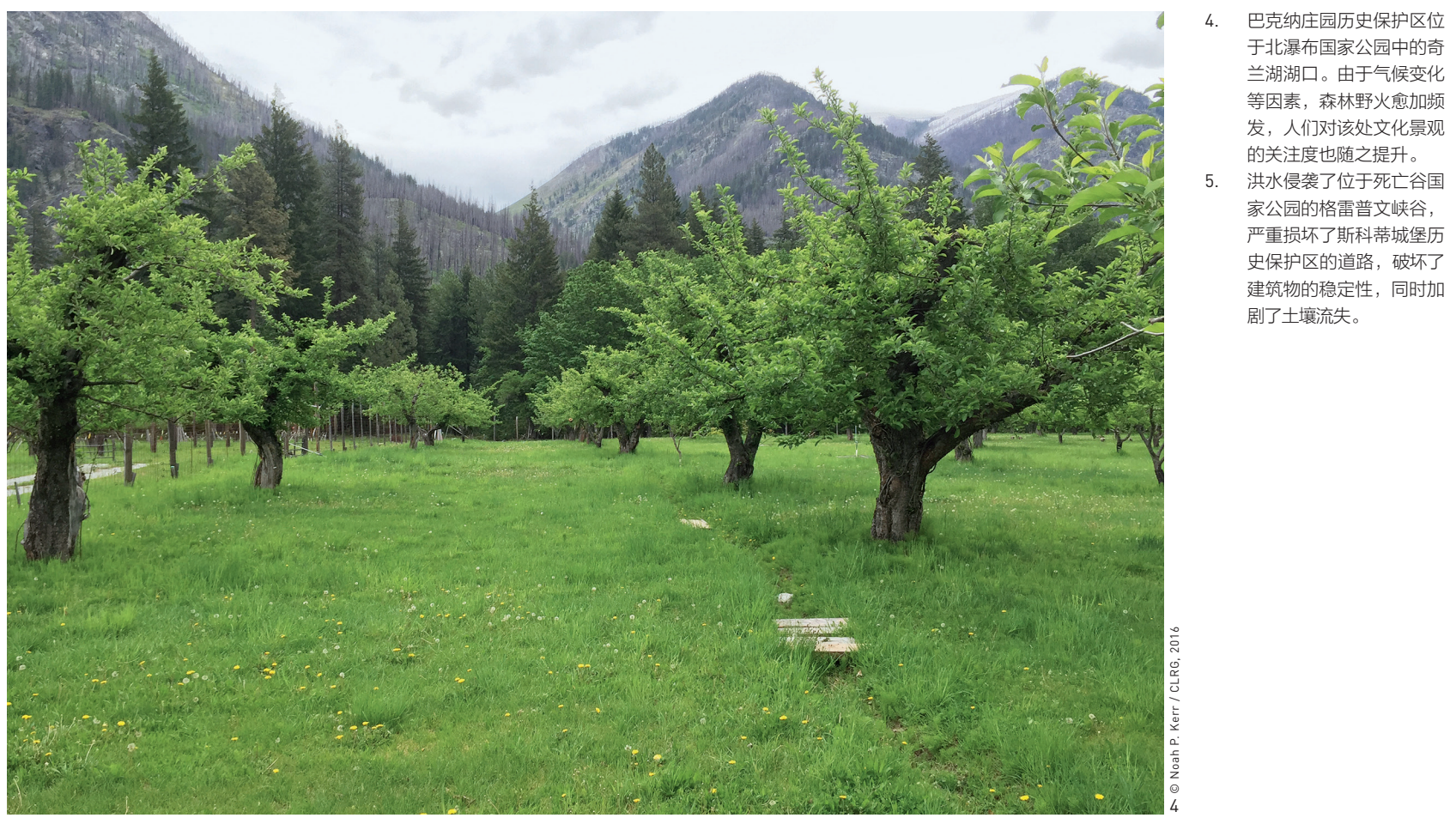
Buckner Homestead Historic District is situated near the head of Lake Chelan in North Cascades National Park. Increased wildfire frequency has heightened concern for cultural landscape resources here, potentially exacerbated by climate drivers.
5. Aftermath from a severe flood event in Grapevine Canyon located in the Death Valley National Park, which damaged roads, destabilized buildings, and triggered extensive soil erosion in Scotty's Castle Historic District.


4个方面对每处文化景观进行评分：1) 场地 现状：对于场地的总体景观状况进行评估, 包括基于CLI框架对其状况进行阐释；2）当 前风险：辨别面临气候灾害风险的文化景观 特征的空间特性 (该赋值根据对当前GIS数 据分析得出 )； 3 ) 历史风险: 主要通过基于 CLI的分析, 确定已知的当前及历史影响; 4 ) 预测风险: 基于气候预测报告中的温度、 海平面和降水量等数据对气候预测数据的 强度和可信度进行计算 ( 数据来源于美国郡 县级尺度的气候预测和对外公布的公园尺度 数据)。在第二阶段, 项目团队对巴克纳庄 园、死亡谷斯科蒂城堡和里昂牧场三处场地 的文化景观特征脆弱性进行了详细研究。两 个阶段的研究成果都将在未来为历史文化景 观的保护工作提供重要依据。

\section{团队协作}

研究团队对CLI数据库中每个场地的信 息进行了分析, 并从各类已发表的和可获取 的数据源中检索气候变化预测数据。通过这 一过程, 我们明确了已经认定的文化景观特 征所面临的来自气候变化的潜在压力和影 响。在NPS区域部门及公园工作人员的协助 下, 团队不仅获取了众多共享数据, 更收集 了来自各方的意见, 充实了现有文献和一手 资料, 并与工作人员建立起了良好的沟通机 制。这一过程需要定量和定性这两种类型数 据的共同支持。

在这些案例研究中, 项目团队十分重视 在各区域和公园园区工作人员的协助下进行 现场调查和文件记录, 以更好地认识各种因 素对当前文化景观特征的影响, 进而深入理 解这些景观的历史形态和意义。项目所施行 的现场调查采用初步踏勘的方法, 拍照记录 了景观系统、地貌、植被、建筑物、景观结 构及其他景观特征的信息, 以记载并评估景 观的状况和影响。通过这一方式, 研究人员 更加充分地了解了公园管理事务中的重点、 对专业工作人员和资金支持的迫切需求, 以 及现有的历史气候数据和预测气候数据之间 存在差值的原因。

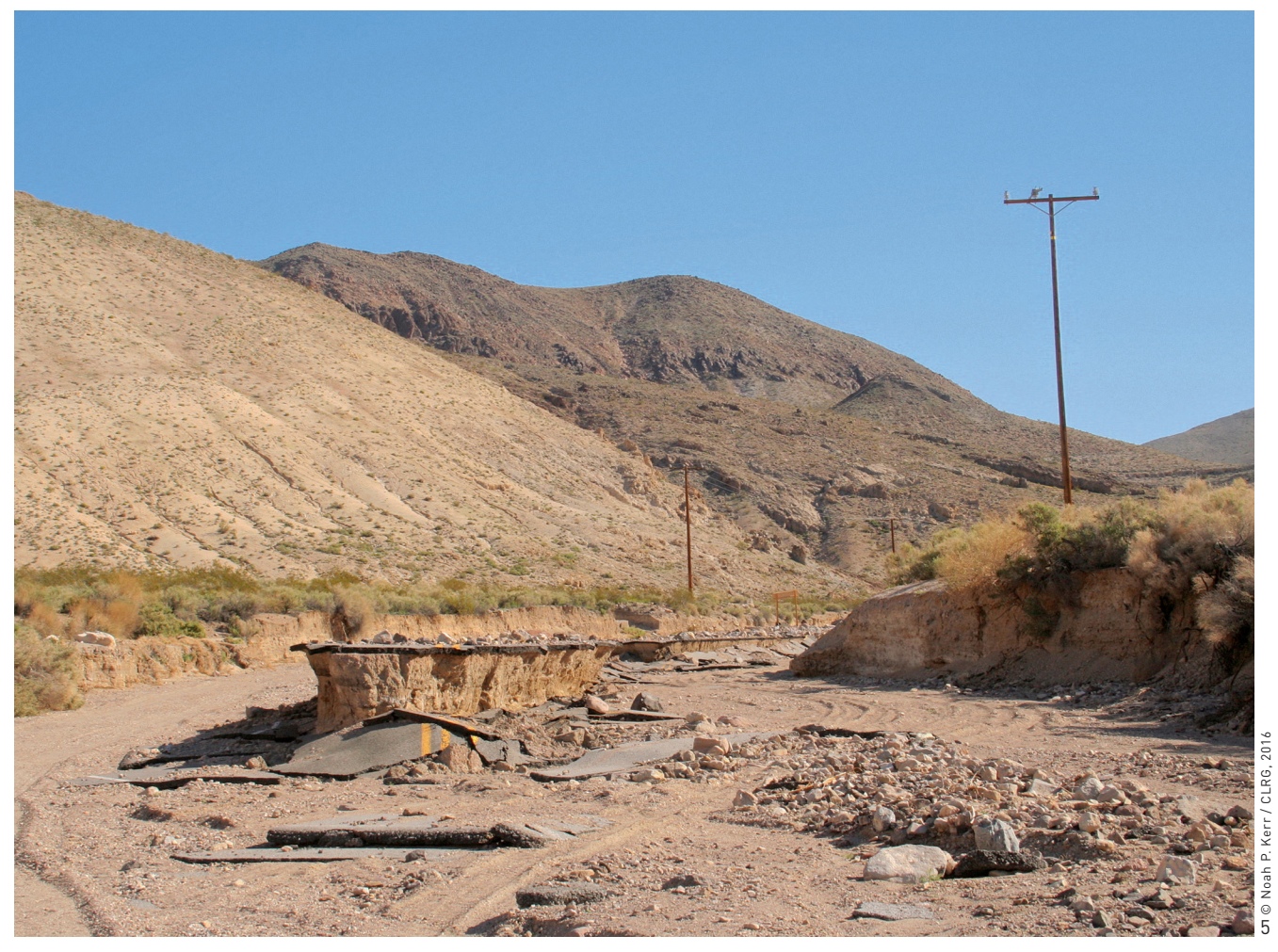

结语

文化景观充满活力且不断发展演变, 其独特的魅力赋予了我们无尽的遐想。但从 现有的评估和管理方案来看, 随着时间的推 移, 仍需挖掘一种易控的、可预测的均衡体 系来管理这些场所 ${ }^{[19]}$ 。而这一体系必须能 够及时更新, 以有效应对不断变化的气候状 况。无论是保有对文化景观中受到保护的历 史属性的清晰认识, 还是根据国家史迹名录 (NRHP) 和CLI的标准进行评估都已变得 愈发困难。然而, 我们仍然能够看到园艺师 试图延迟观赏植物衰老期的到来, 或是修复 古建筑的工匠正面对越来越稀缺的老龄木材 而苦苦挣扎 ${ }^{[20]}$ 。对于文化景观管理者来说, 能够灵活而创造性地应对基于场地发展的新 兴思潮和需求, 将成为其职业素养的核心。 2016年是美国《NPS组织法》颁布100周 年, 它不仅见证了时间的流逝, 更记录了公 园管理工作的悄然发展。
我们应当始终将文化景观视为不断发展 的过程和物质体系, 而非仅仅存在于某个场 地中的珍宝。当意识到气候变量作为可变因 素的关键作用之后, 我们应更加明确将文化 景观固有体系的变化与气候变化中隐含的 不确定性因素区分开来的必要性。在此基础 上, 我们可以了解已知和预测的气候变化对 公园特征的关键影响, 进而深入理解安吉 拉·里奇曼所强调的公园遗产中文化景观的 “全貌” [21]。这既是机会也是挑战, 需要引起 更加广泛的关注。LAF

注释

该项目研究成果及最新报告《气候变化与文化景观: 研究、规 划与管理指南》均由CLRG 研究人员编写并授权国家公园管理 局发布, 欲了解详细内容请访问https://www.nps.gov/subjects/ culturallandscapes/climate-change.htm。 


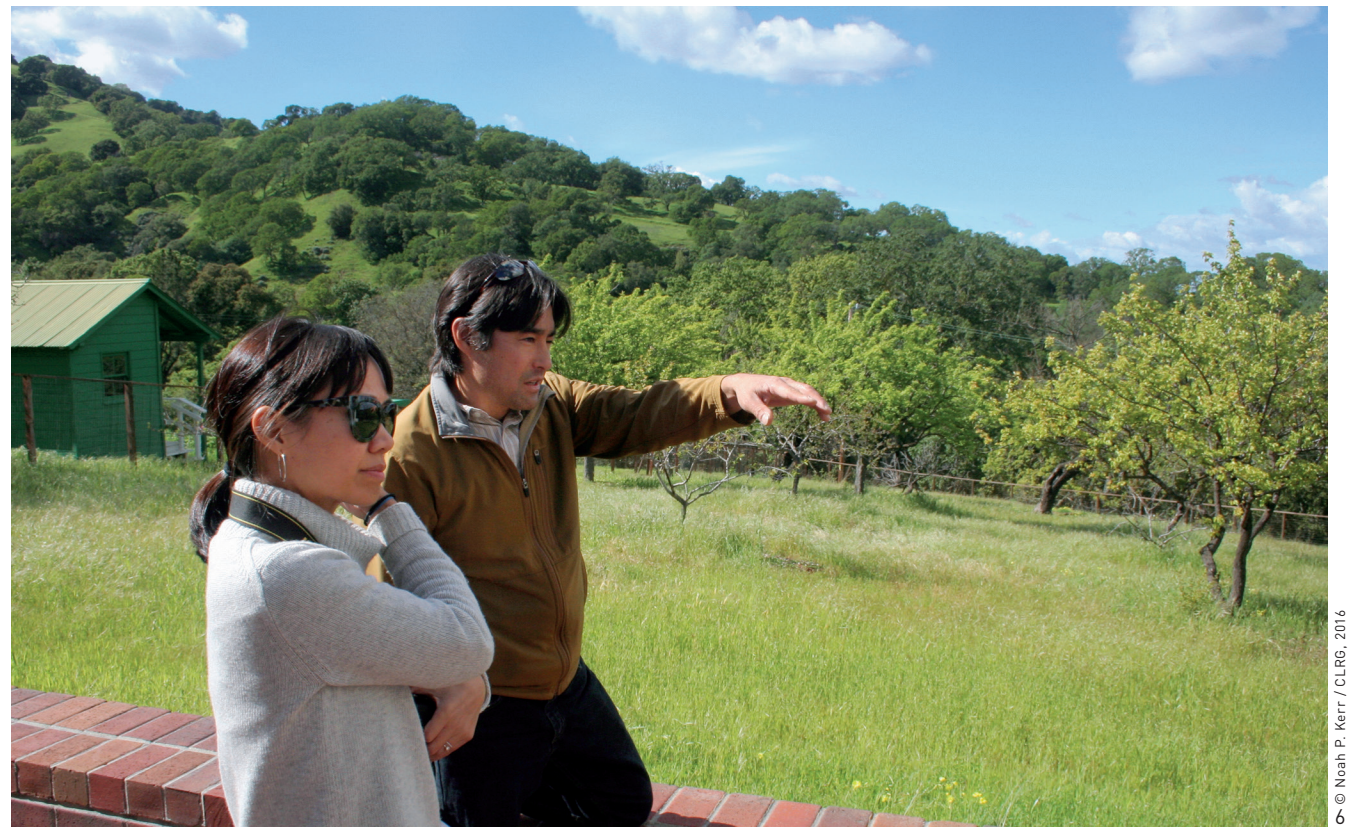

\section{Introduction}

During the past half-century, the U.S. National Park System (NPS) has advanced the recognition of its cultural resource inheritance. The Cultural Landscape Inventory (CLI) system, in particular, offers a case in point ${ }^{[1][2]}$. From the $1960 \mathrm{~s}$ forward, expanding consideration for significant landscapes through prepared Historic Grounds Reports and formal recognition of historic sites (1968) communicated a broadening perception of cultural significance in the wake of

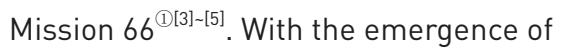
technical guidance by the early 1980 s, such as Cultural Landscapes: Rural Historic Districts in the National Parks, this realm of resource stewardship highlighted a deeply entwined relationship: these resources exist as a nexus of distinct human and natural forces acting upon the land ${ }^{[6]}$. Moreover, their lasting historic character remains defined by it and, as Ludomir Lonzy urges, this engenders a simultaneous experience of natural and cultural realms ${ }^{[7]}$. This relationship continues to inform NPS management practice today, underlining these places' inherent biological and cultural dynamism. Moreover, it guarantees persistent - and at times frustrating - changes in their distinguishing features: heritage plantings reach the end of their natural lifespan; rain and wind wear at soil. Effective stewardship requires accommodating change at one scale while managing and even slowing it at another.

Climate change now brings a new enigma to our conception and care of these places. How might shifting systems, both natural and human, influence the efficacy of existing tools in landscape preservation, such as techniques used for periodic condition assessment? The proverbial target appears to be moving, perhaps indefinitely. Projected shifts in familiar ranges of climate means and extremes invoke disquieting prospects for long term trends, including alterations to air temperature and precipitation. Concern regarding changing sea level, affecting coastal environs such as Pu'ukohola Heiau National Historical Site on Hawaii, suggests one expression of potential climate hazards. Additionally, increased frequency and intensity in wildfires, among other threats, continue to loom over parklands from Yosemite National Park to Washington's Lake Chelan National Recreation Area.

At its core, acknowledging uncertainty is central to this endeavor, and is particularly important for a region encompassing diverse land forms and systems, such as the Pacific West Region (PWR) of NPS. Yet severe climate events frequently demonstrate a recognizable effect, and are rightly concerning. In one recent instance, in Death Valley National Park, convective rainfall triggered the October 18, 2015 flash flood of Grapevine Canyon; in two days, the locale received the rough equivalent of its annual historical norm, well beyond the levels accompanying a hundred-year event ${ }^{[8][9]}$. Flooding wrought havoc across Death Valley Scotty Historic District, with 
6. 俄勒冈大学文化景观 于美国国家公园管理系 统大平洋没岸地区的园 艺师正在讨论尤金-奥尼 尔国家历史遗址在文化 景观管理工作上面临的 挑战。

在巴克纳庄园历史保护 区, 一个木制的涵洞仍 然保留于人工开挖的沟 渠系统中, 用于灌溉这 里的传统果园。此类文 化景观具有重要的历史 价值, 且并未受到园区 果农所采取的场地保护 管理措施的影响。
6. A member of the CLRG research team and PPS PWR horticuturist NPS PWR hortic discuss cultur

landscape managemen challenges emerging at Eugene 0'Neill National Historic Site.

7. A wooden culvert maintained as a working component in this hand-dug ditc system is still used to irrigate heritage orchards at Buckner Homestead Historic District. Such cultural landscape features are and compatible with preservation management practices used by the park orchardist. discharge exceeding $85 \mathrm{~m}^{3} / \mathrm{s}$. To effectively gauge the implications of potentially more frequent such extremes for cultural landscape features beyond a single park setting, managers would benefit from a systematic means of distinguishing baseline conditions $^{[10]}$.

\section{Cultural Landscape Inventory and Climate Adaptation Strategies}

CLI is a certified database of all significant landscapes in NPS. Each CLI document assesses the history and conditions of a specific cultural landscape, including the known effects of historical change. In this project, data pertaining both to overall condition and recorded impacts for each cultural landscape were overlaid with, and analyzed according to current climate change projection data. This process follows the existing stewardship framework of the

CLI, and is intended to identify and potentially quantify anticipated climate change impacts. In partnership with NPS, the team refined the agency's recent framework for cultural resource climate change response ${ }^{[11][12]}$, to better understand projected climate change impacts to cultural landscapes located in the western United States and Pacific Islands.

This work was conducted over two years by the University of Oregon's Cultural Landscape Research Group (CLRG), in two project phases, with close collaboration with PWR staff. Working with climate scientists and other landscape stewards, the research team first compiled localized (i.e. countylevell projections to assess how documented cultural landscapes within the region might be affected by selected climate variables.

The resulting matrix summarizes all character-defining features and documented impacts for 164 cultural landscapes across the region. Each of these places meets CLI certification requirements.

Matrix development also prompted

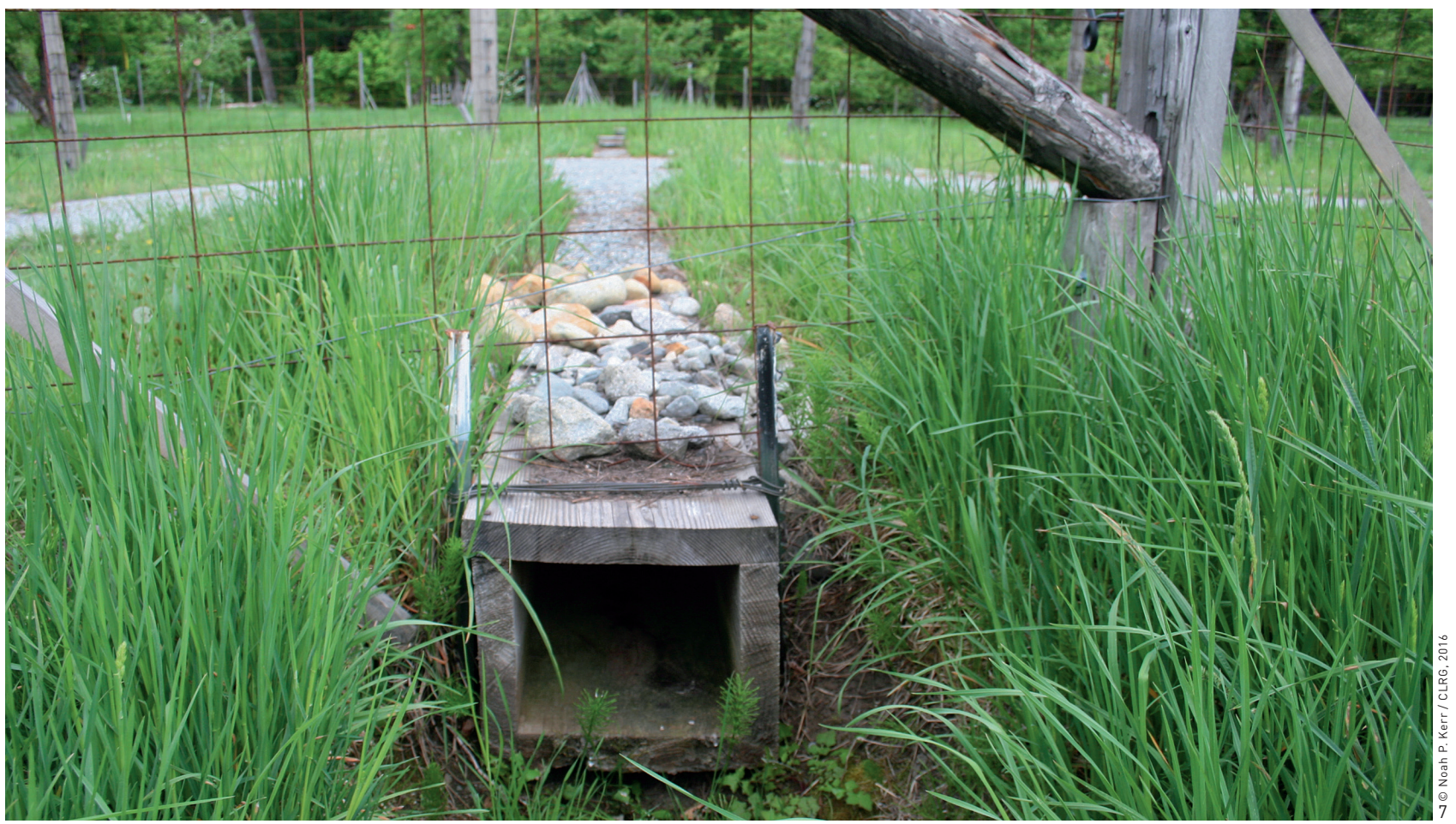




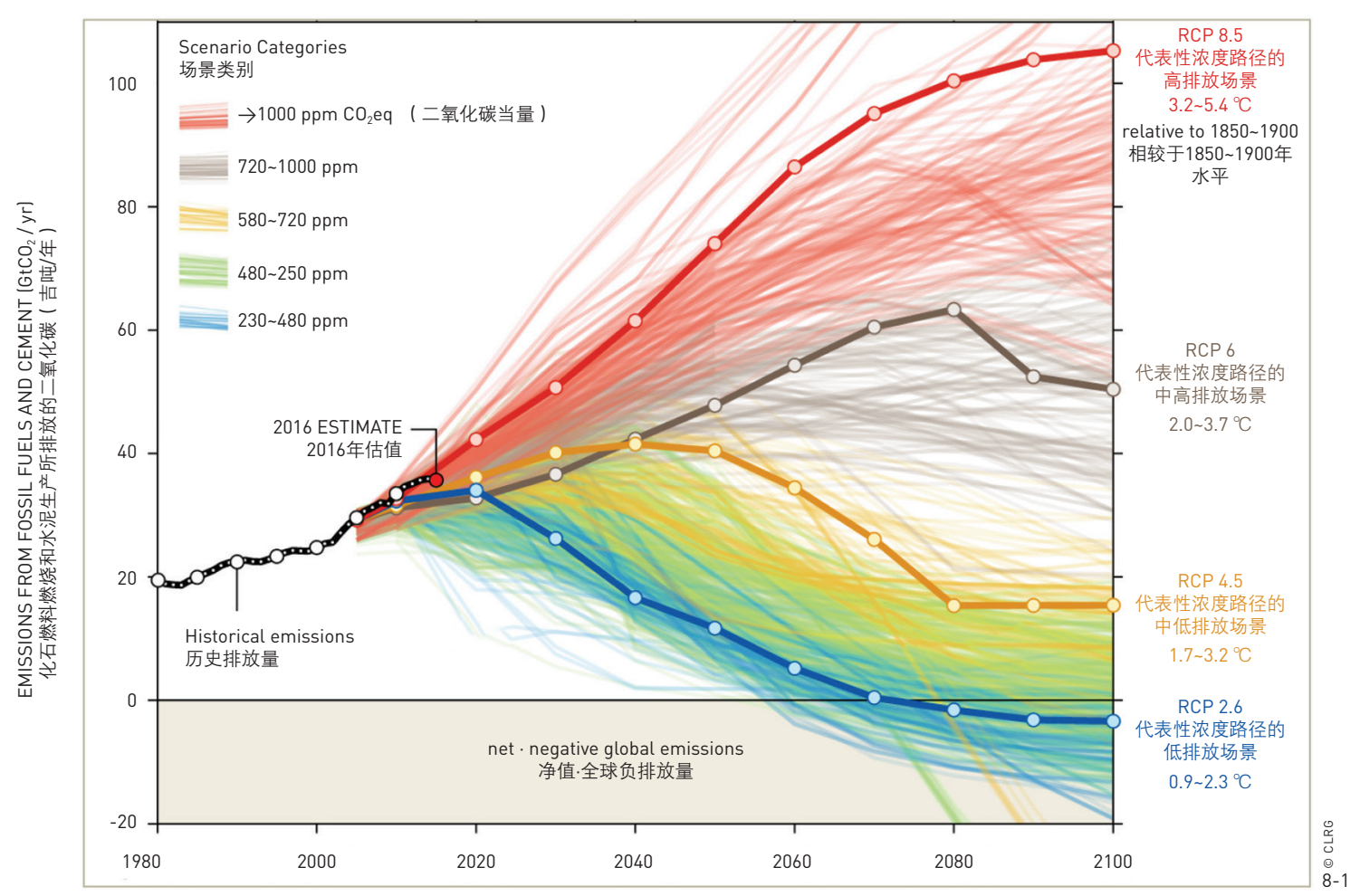

early development of an analytical model. This tool is intended to quantify cultural landscape vulnerability as a function of individual landscape features. Aggregated scoring for each landscape summarizes exposure according to several known environmental hazards and key projected climate changes - enabling future comparisons related to sites' exposure to both current risk and projected climate change. Six field case studies offered opportunities to refine - or "ground truth" - identification of current conditions, viewed through the lens of selected climate variable projections. Three of the above case studies were revisited, in order to inform preliminary vulnerability assessments. Together, this work informs recommendations for future research toward the agency's goal of ensuring cultural landscapes' resilience in the era of climate change.

\section{Selection of Sites for Case Study}

Six case studies were selected using three criteria: 1) each is located in a different PWR network la unit of organization roughly analogous to an ecological region); 2) all cultural landscape types recognized by NPS were represented (i.e. historic site, vernacular, design, ethnographic); and 3) that park staff were available to participate and assist with fieldwork and research. Case study selection resulted in the following field locations: Lyons Ranches Historic District, Redwood National Park, California; Death Valley Scotty Historic District, Death Valley National Park, California; Eugene
O'Neill National Historic Site, California; Buckner Homestead, North Cascades National Park, Washington; Pu'ukohola Heiau National Historic Site, Hawaii; Heart of the Monster, Nez Perce National Historical Park, Idaho.

\section{Project Objectives}

The project aims to 1) collect and compile climate change projection data for 164 cultural landscapes in 43 parks across the PWR, including, but not limited to, climate change trends in air temperature, precipitation, and sea level; 2) identify anticipated climate change related exposures specific to each of the 164 cultural landscapes; 3) conduct six case studies, assessing current condition and impacts in selected cultural landscapes, and 
8-1. 美国国家公园管理系 统太平洋沿岸地区预 测气候变量中的污染气 体排放量 (历史值与愿 景值）。为实现项目目 标, 气候分析与文化景 观评估均基于代表性浓 度路径的高排放场景 ( RCP 8.5) 进行。详情 参见: 参考文献[22]。

8-2. 美国国家公园管理系统 太平洋沿岸地区预测气 候变量中的预测气温。

在代表性浓度路径的高 排放场景（RCP 8.5 下, 到2100年, 全球平 均气温相较于1950年将 上升 $3.3^{\circ} \mathrm{C}$
8-1. The observed emissions and projected emissions scenarios, one of the projecting climate variables in NPS PWR. For the purposes of this project, climatic analyses and cultural landscape assessments are based on the highest emissions scenario, RCP 8.5. Se scenario, RCP 8.5.

8-2. The projected temperature, one of the projecting climate variables in NPS PWR. Under the highest emissions projection (RCP 8.5), average air temperature is projected to increase by $3.3^{\circ} \mathrm{C}$ by the year 2100 relative to 1950 identifying steps towards ensuring impacts are addressed, to improve the landscape's resiliency; 4) conduct additional work on three of the six case studies, assessing preliminary vulnerability of the cultural landscape features to the known and projected climate variables, as previously identified (within Phase I).

\section{Methods}

This project approach tested and refined an existing framework for managing the projected effects of climate change, in a new cultural landscape format. For each site, the basic formula adopted to express vulnerability to climate variables is as follows:

(exposure + sensitivity) / adaptive capacity $=$ vulnerability ${ }^{[13]}$

\section{Climate Projections}

Due to varying availability of data for study sites, the team delineated its analysis to consider projections for temperature, precipitation, and sea level. This scope adopts regional climate projections from a variety of peer-reviewed sources, with respect to Intergovernmental Panel on Climate Change (IPCC) Representative Concentration Pathway (RCP) emissions pathway $8.5^{[14] \sim[17]}$.

\section{Hazards}

Geographic Information System (GIS) analysis evaluated hazards associated with projections. Hazards include drought, fire, flood, and landslide - derived from established risk data published by a range of federal agencies, including the National Oceanic and Atmospheric Administration
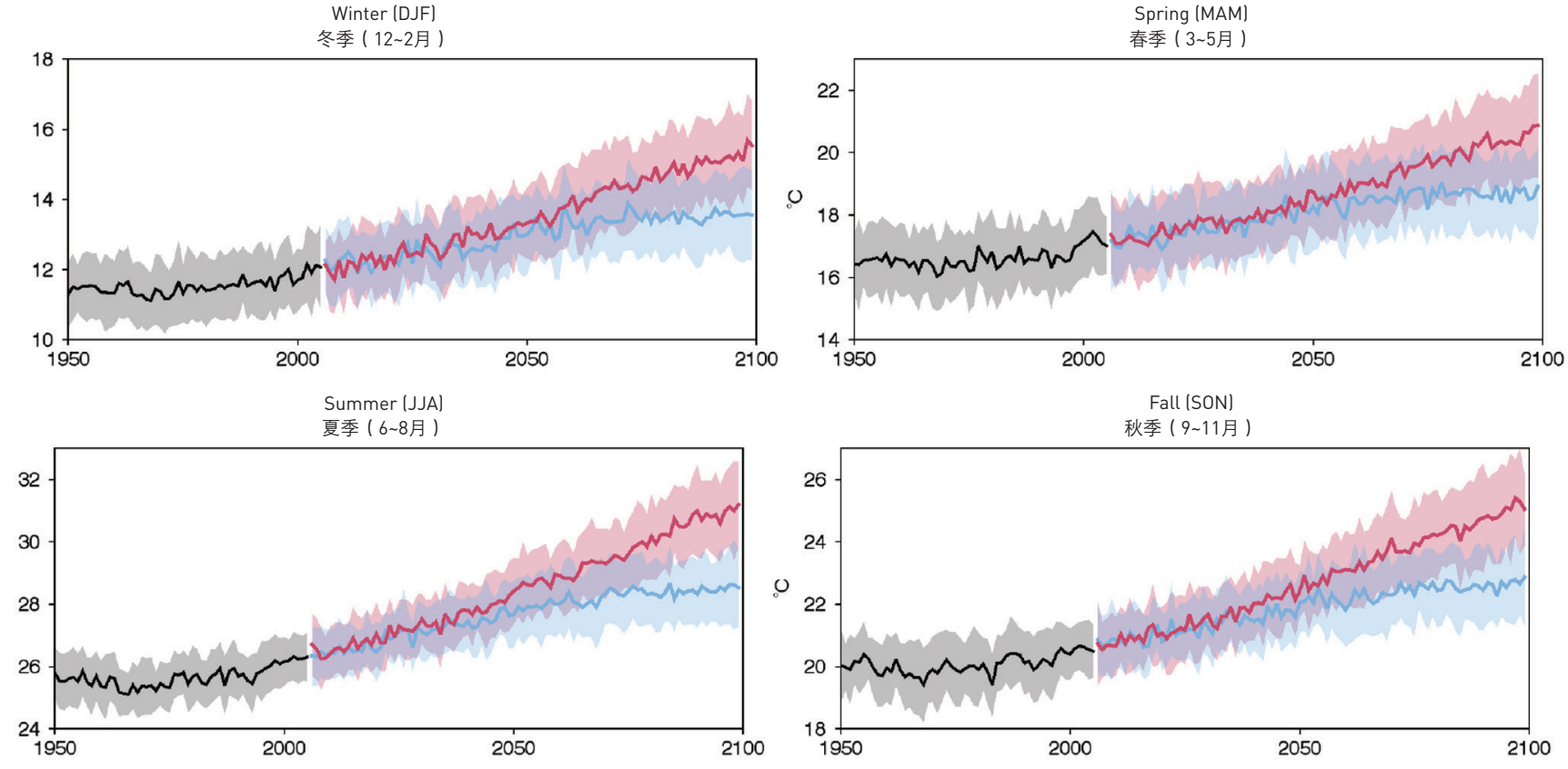

Seasonal average time series of maximum 2-m air temperature for historical (black). RCP 4.5 (bluel and RCP 8.5 (red). The average of $30 \mathrm{CMIP5}$ models is indicated by the solid lines and their standard deviations are indicated by the respective shaded envelopes. See Ref [23]. 式比较计划第五阶段试验计划 ( CMIP5) 中 30 个模型的均值在图中呈现为实线, 阴影处为各时间序列下各自的标准差。详情参见: 参考文献 233 . 


\begin{tabular}{|c|c|c|c|c|c|c|c|}
\hline $\begin{array}{c}\text { Park Alpha } \\
\text { Code } \\
\text { 公园字母代码 }\end{array}$ & $\begin{array}{c}\text { Cultural Landscape Inventory Name } \\
\text { 《文化景观名录》目录 }\end{array}$ & $\begin{array}{l}\text { Condition Score } \\
\text { 现状评分 }\end{array}$ & $\begin{array}{c}\text { Current } \\
\text { Exposure Score } \\
\text { 当前风险评分 }\end{array}$ & $\begin{array}{c}\text { Historical } \\
\text { Exposure Score } \\
\text { 历史风险评分 }\end{array}$ & $\begin{array}{c}\text { Combined Condition, } \\
\text { Current, and } \\
\text { Historical Exposure } \\
\text { Score } \\
\text { 现状、当前风险和历 } \\
\text { 史风险综合评分 }\end{array}$ & $\begin{array}{c}\text { Projected } \\
\text { Exposure Score } \\
\text { 预测风险评分 }\end{array}$ & \\
\hline LAVO & $\begin{array}{l}\text { Drakesbad Guest Ranch } \\
\text { 德雷克斯巴德宾客牧场 }\end{array}$ & $66.00 \%$ & $2.36 \%$ & $9.39 \%$ & $7.76 \%$ & 1.26 & \\
\hline LAVO & $\begin{array}{l}\text { Lassen Volcanic National Park Highway } \\
\text { 拉森火山国家公园高速公路 }\end{array}$ & $66.00 \%$ & $0.00 \%$ & $4.55 \%$ & $3.00 \%$ & 2.25 & \\
\hline LAVO & $\begin{array}{l}\text { Mineral Headquarters Historic District } \\
\text { 矿产总部历史保护区 }\end{array}$ & $33.00 \%$ & $0.00 \%$ & $12.53 \%$ & $4.14 \%$ & 2.25 & \\
\hline MANZ & $\begin{array}{l}\text { Manzanar National Historic Site } \\
\text { 曼扎拿国家历史遗址 }\end{array}$ & $66.00 \%$ & $7.52 \%$ & $11.88 \%$ & $12.80 \%$ & 4.11 & \\
\hline MIIN & $\begin{array}{l}\text { Minidoka Internment National Monument } \\
\text { 米尼多卡集中营国家纪念碑 }\end{array}$ & $100.00 \%$ & $2.84 \%$ & $2.55 \%$ & $5.39 \%$ & 3.67 & \\
\hline MOJA & $\begin{array}{l}\text { Kelso Depot } \\
\text { 科尔索火车站 }\end{array}$ & $100.00 \%$ & $0.44 \%$ & $4.50 \%$ & $4.94 \%$ & 4.67 & \\
\hline MOJA & $\begin{array}{l}\text { Mescal Historic Mining District } \\
\text { 梅斯卡尔历史矿区 }\end{array}$ & $66.00 \%$ & $1.70 \%$ & $3.85 \%$ & $3.67 \%$ & 4.67 & \\
\hline MOJA & $\begin{array}{l}\text { Rock Springs Land and Cattle Company } \\
\text { 罗克斯普林斯农业与畜牧业公司 }\end{array}$ & $66.00 \%$ & $0.05 \%$ & $1.03 \%$ & $0.71 \%$ & 4.67 & \\
\hline MOJA & $\begin{array}{l}\text { Soda Springs Historic District } \\
\text { 苏打斯普林斯历史保护区 }\end{array}$ & $66.00 \%$ & $0.00 \%$ & $15.92 \%$ & $10.51 \%$ & 4.67 & \\
\hline MOJA & $\begin{array}{l}\text { Vulcan Mine Historic District } \\
\text { 伏尔甘矿历史保护区 }\end{array}$ & $66.00 \%$ & $2.78 \%$ & $3.21 \%$ & $3.94 \%$ & 4.67 & \\
\hline MORA & $\begin{array}{l}\text { Camp Muir } \\
\text { 缪尔营地 }\end{array}$ & $66.00 \%$ & $5.56 \%$ & $9.72 \%$ & $10.08 \%$ & 2.25 & \\
\hline MORA & $\begin{array}{l}\text { Christine Falls } \\
\text { 克莉丝汀瀑布 }\end{array}$ & $33.00 \%$ & $0.00 \%$ & $11.67 \%$ & $3.85 \%$ & 2.25 & \\
\hline MORA & $\begin{array}{l}\text { East Side Highway } \\
\text { 东区公路 }\end{array}$ & $33.00 \%$ & $0.00 \%$ & $3.21 \%$ & $1.06 \%$ & 2.25 & \\
\hline MORA & $\begin{array}{l}\text { Longmire Developed Area } \\
\text { 朗迈尔氏发达地区 }\end{array}$ & $66.00 \%$ & $0.34 \%$ & $5.76 \%$ & $4.02 \%$ & 2.25 & \\
\hline MORA & $\begin{array}{l}\text { Mather Memorial Parkway (Route 410) } \\
\text { 马瑟纪念公园大道 ( } 410 \text { 号公路 ) }\end{array}$ & $66.00 \%$ & $2.56 \%$ & $11.47 \%$ & $9.27 \%$ & 2.25 & High 高风险 \\
\hline MORA & $\begin{array}{l}\text { Mowich Lake Entrance Road } \\
\text { 莫伊奇湖入口公路 }\end{array}$ & $33.00 \%$ & $1.85 \%$ & $2.81 \%$ & $1.54 \%$ & 2.25 & $\begin{array}{l}\text { Medium 中风险 } \\
\text { Low 低风险 }\end{array}$ \\
\hline
\end{tabular}

(NOAA), United States Geological Survey (USGS), and the United States Forest Service (USFS).

\section{Impacts}

The team analyzed documented impacts to each specific cultural landscape, selected from an existing CLI conditional assessment typology, including disruption; loss of plant species; erosion; exposure to elements; neglect; pests / diseases; pruning practices; release to succession; structural deterioration; temperature / hot extremes; temperature / warmer averages; and vegetation / invasive plants. Impacts are tracked by NPS for all cultural landscapes. For case studies, each impact was verified and documented in the field.

\section{Results}

In Phase I, 2016 efforts introduced a vulnerability assessment-focused matrix, as a means to index exposure of characterdefining cultural landscape features.

Based on publicly available climate change projection data, exposure describes "the presence of people, livelihoods, species 
9. 从分析模型中提取的样 本数据，可协助NPS 理人员评估某处区域所 记录的文化景观面临的 预测气候风险。

10. 位于普乌科侯拉神庙国 家历史遗址的传统干砌 石结构。在田野调查 中, 我们记录下了可能 改变这些神圣构筑物结 构的野山羊的行踪。
Sample data from a component of the analytical model, developed to assist NPS stewards in assessing projected climate exposure among the region's documented cultural landscapes.
10. Traditional dry-laid masonry construction located in Pu'ukohola ceian Nation Heiau National Historical Site. The activity of wild goats, which can alter these sacred structures, was documented during

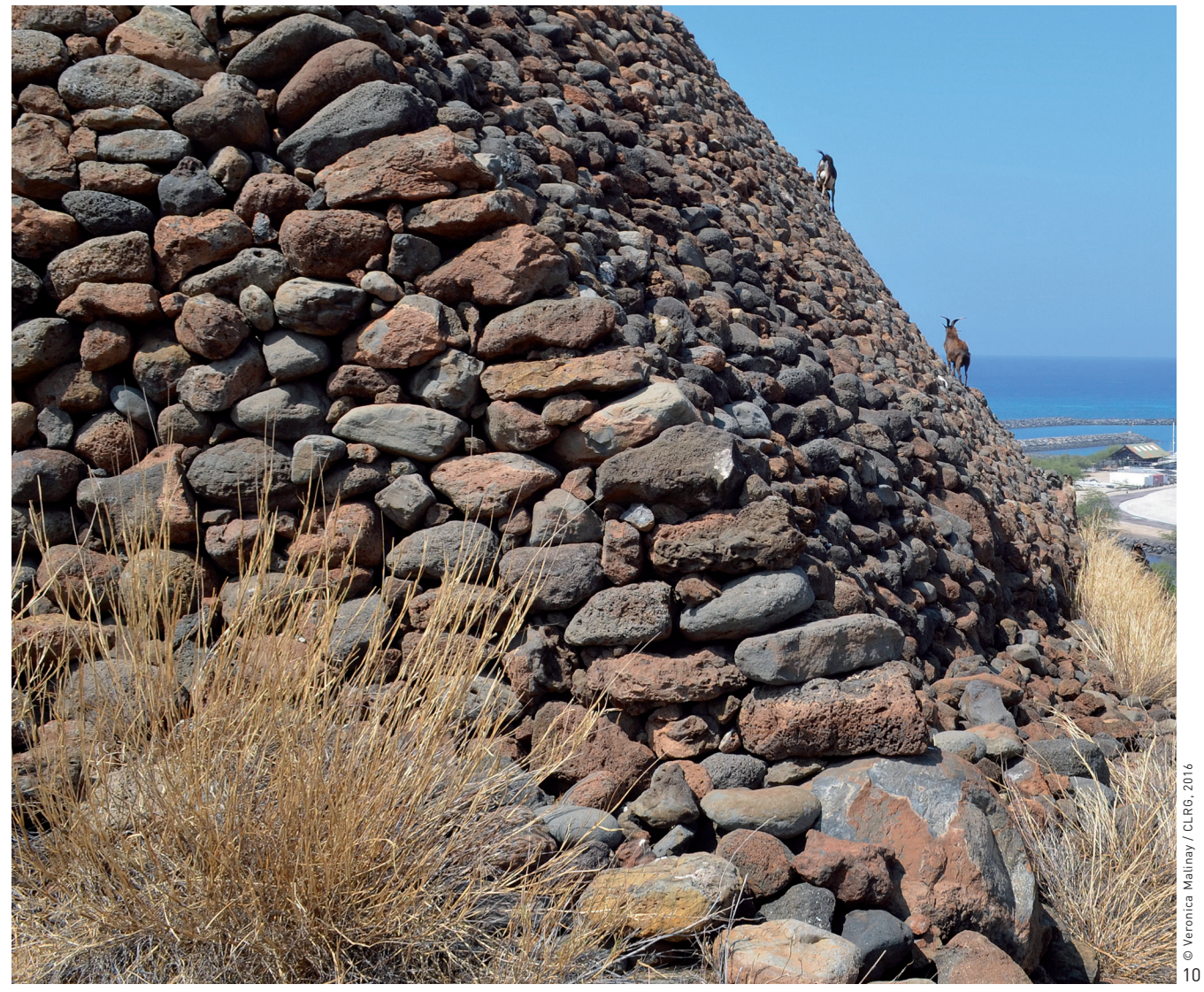

landscape features at risk to a climate hazard (this assigned value is predicated on analysis of current GIS data); historical exposure, identification of known current and historical impacts, primarily through $\mathrm{CLI}$ analysis; and projected exposure informed by the climate projections for temperature, sea level, and precipitation, which is a calculation of intensity and confidence of climate projection data Idatasets are comprised of current climate projections delineated along U.S. county boundaries, as well as at park scale where available). Phase II of the study was conducted through detailed case studies of vulnerability at Buckner Homestead, Death Valley Scotty Historic District, and Lyons Ranches. Both phases will inform future management decisions for conservation of significant historic resources.

\section{Collaboration}

Team members analyzed the CLI database for each site and retrieved climate projection data from a variety of published and available data sources. This process shaped a determination of potential climate stresses and impacts on identified cultural landscape characteristics and features. Consultation with NPS regional and park staff enabled data sharing, collecting additional observations, and gathering new recommendations for current literature and primary source materials, as well as inviting further staff advice. The process employed both quantitative and qualitative data.

Case studies stressed field investigation and documentation of each site with regional and park staff, to achieve a better grasp of current impacts on cultural 


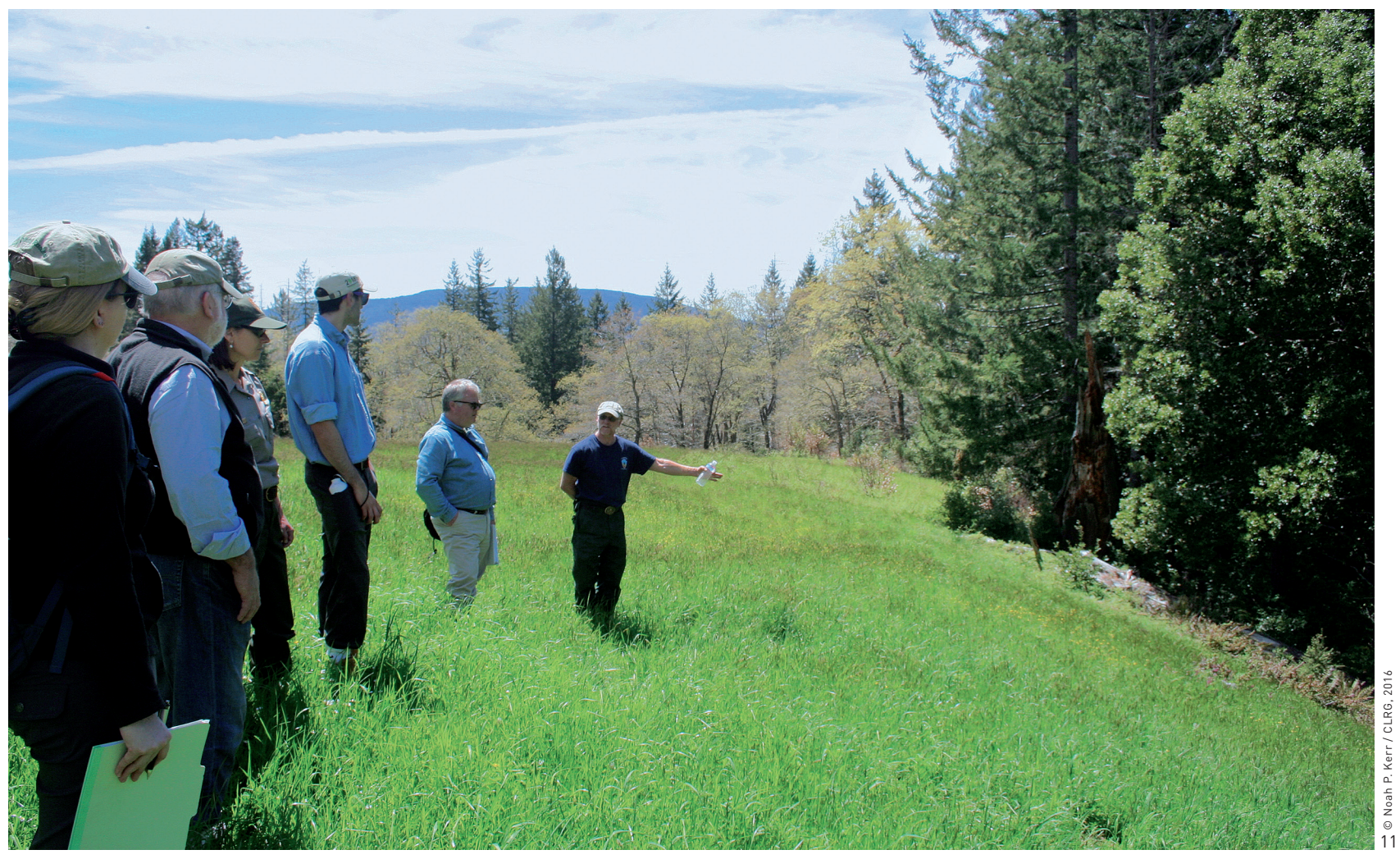

11. 公园工作人员和研究人 员正在讨论应用于里昂 场中的火灾生态学和 然料管理实践, 该处文 化景观与红杉树国家公 园中的巴尔德山原生山 地草原相互交织。如何 维护䴤鹿营等场地中草 原物种的活力和多样性 仍颇具挑战性。

11. Park staff and researchers discuss fire ecology and fuels management practices used at Lyons Ranches, a cultural landscape interwoven with the native upland prairies of Redwood National Park's Bald Hills. Maintaining the visibility and composition of prairie species at sites like Elk Camp remains challenging.

landscape features that contribute to the understanding of the landscape's historic form and significance. Fieldwork followed a regimen of visual inspection and logged photo-documentation of landscape

systems, topography, vegetation, buildings, structures, and other landscape features to document and assess condition and impacts. This offered researchers additional insight into park priorities, competing demands for staff expertise and funding, and the acknowledged gaps in available historical and projected climate data.

\section{Concluding Comments}

Cultural landscapes continue to invite our fascination as living, evolving systems. Yet existing evaluation and management protocols retain the underlying assumption that a controlled, predictable equilibrium governs these places over time ${ }^{[19]}$. This paradigm must shift along with effective climate response tools. Maintaining a clear sense of some historic attributes protected in these sites, meanwhile - as evaluated according to National Register of Historic Places (NRHP) and CLI protocols becomes an increasingly slippery prospect. A horticulturalist works to delay entropy in elderly specimen plants, while a preservation carpenter grapples with an increasingly scarcity of old-growth timber for historically appropriate building repairs ${ }^{[20]}$. The flexibility, and sometimes creativity, on the part of cultural landscape managers to respond to a guiding ethos and emerging needs onsite seems to comprise an increasingly vital aspect of their professional vocation. The passage of time marked in the 2016 NPS Organic Act centenary serves as a reminder of the depth of such changes quietly at work.
We must continue to understand cultural landscapes as processes and systems, rather than simply treasured objects gathered in the open air. Recognizing the critical role of climate variables as moving parts amplifies the need to differentiate inherent system change from the uncertainty implicit in climate shifts. To do so appreciates known and projected climate impacts together as a key influence upon park character, enabling us to better engage what Angela Richman emphasizes as the "whole story" of cultural landscapes in the Park legacy ${ }^{[21]}$. It is an opportunity and a challenge in need of attention. LAF

NOTE

Findings from these efforts, as well as the recent Climate Chang and Cultural Landscapes: A Guide to Research, Planning and Stewardship, were authored by CLRG researchers, and are made publically available through the National Park Service: https:// www.nps.gov/subjects/culturallandscapes/climate-change.htm. 
[1] Dolan, S. (2013, December). NPS Park Cultural Landscape Program Methodology. Presentation to 4th National Register Landscape Initiative Webinar. Retrieved from https://www. nps.gov/nr/publications/guidance/NRLI/presentations/1 NRLI_NPS_Intro_Cultural_Landscapes_S_Dolan.pdf

[2] Brown, N. (2001). More than a database: the National Park Service's Cultural Landscapes Inventory improves resource stewardship. In D. Harmon (Ed.), Crossing Boundaries in Park Management: Proceedings of the 11th Conference on Research and Resource Management in Parks and on Public Lands (pp. 311-315). Hancock: George Wright Society.

[3] Page, R. R., Gilbert, C. A., \& Dolan, S. A. (1998). A Guide to Cultural andscape Reports: Contents, Process, an Techniques (pp. 10-11). Washington, D.C.: National Park Service.

[4] Melnick, R. Z. (1983). Protecting Rural Cultural Landscapes: Finding Value in the Countryside. Landscape Journal, 2(2) . $85-$ 96.

[5] Birnbaum, C. A. Barrett, H. L. \& Shillinglaw, E. (Eds.). (2000) Making Educated Decisions: A Landscape Preservation Bibliography 2. Washington, D.C.: National Park Service, Historic Landscape Initiative.

[6] Melnick, R. Z. (1984). Cultural Landscapes: Rural Historic Districts in the National Park system. Washington, D.C. Park Historic Architecture Division, Cultural Resources Management, National Park Service, U.S. Department of the Interior.

[7] Lozny, L. R. (2006). Place, Historical Ecology and Cultura Landscape: New Directions for Culture Resource Management. In L. R. Lozny (Ed.J. Landscapes Under Pressure: Theory and Practice of Cultural Heritage Research and Preservation (pp. 15-26). New York: Springer.

[8] Bowers J C. (1990). Potential Hazards from Floodflows in Grapevine Canyon, Death Valley National Monument, California and Nevada. Water-Resources Investigations (Report 89-4063). Sacramento: U.S. Geological Survey.

[9] Medlock, K. (2015). 1,000-year-flood Devastates Death Valley and El Niño Threatens More. Retrieved from https:// inhabitat.com/1000-year-flood-devastates-death-valleyand-el-nino-threatens-more/

[10] National Academies of Sciences, Engineering, and Medicine. (2016). Attribution of Extreme Weather Events in the Context of Climate Change (pp. 25-27). Washington, D.C The National Academies Press.

[11] Rockman, M., Morgan, M., Ziaja, S., Hambrecht, G., \& Meadow, A. (2016). Cultural Resources Climate Change Strategy. Washington, D.C.: Cultural Resources, Partnerships, and Science and Climate Change Response Program, National Park Service.

[12] Rockman, M. 2015). An NPS Framework for Addressing Climate Change with Cultural Resources. The George Wright Forum, 32(1), 37-50.

[13] Melnick, R. Z., Kerr N. P., Malinay, V., \& Burry-Trice, 0. (2017). Climate Change and Cultural Landscapes: A Guid to Research, Planning, and Stewardship. Eugene: Cultural Landscape Research Group, University of Oregon.

[14] Alder, J. R., \& Hostetler, S. W. (2016). USGS National Climate Viewer, U.S. Geological Survey. Retrieved from http://www.usgs.gov/climate_landuse/clu_rd/nccv.asp/

[15] Gonzalez, P. (2011). Climate Change Impacts and Carbon in U.S. National Parks. Park Science, 28(2), 10-15.

[16] Monahan, W. B., \& Fisichelli N. A. (2014). Climate Exposure of U.S. National Parks in a New Era of Change. PLoS One, 9(7), e 101302. Retrieved from https://www.ncbi.nlm.nih.gov/pmc/ articles/PMC4079655/

[17] Riahi, K., Rao, S., Krey, V., Cho, C., Chirkov, V., Fischer, G., Peter, R. (2011). RCP 8.5 - A Scenario of Comparatively High Greenhouse Gas Emissions. Climatic Change, (109), 33-57.

[18] Revi, A., Satterthwaite, D., Aragón-Durand, F., Corfee-Morlot, J., Kiunsi, R., Pelling, M., Roberts, D. C., \& Solecki, W. (2014). Urban Areas. In C. B. Field, V. R. Barros, D. J. Dokken, K. J. Mach, M. D. Mastrandrea, T. E. Bilir, \& L. L. White (Eds.), Climate Change 2014: Impacts, Adaptation, and Vulnerability. Part A: Global and Sectoral Aspects. Contribution of Working Group II to the Fifth Assessment Report of the Intergovernmental Panel on Climate Change (pp: 535-612). Cambridge: Cambridge University Press.

[19] Melnick, R. Z. (2015). Climate Change and Landscape Preservation: Rethinking Our Strategies. Change Over Time, 5 (2). 174-179.

[20] National Park Service (1990). Secretary of the Interior's Standards for the Treatment of Historic Properties. Retrieved from http://legacy.historycolorado.org/sites/default/files/files/ OAHP/crforms_edumat/pdfs/1572.pdf

[21] Richman, A. M. (2015). Every Place Has a Climate Story: Interpreting Climate Change at Historic Sites. The George Wright Forum, 32(1), 71-76.

[22] Fuss, S., Canadell, J. G., Peters, G. P., Tavoni, M., Andrew, R. M. Ciais, P., ... Yoshiki, Y. (2014). Betting on Negative Emissions. Nature Climate Change, 4(10), 850-853.

[23] Alder J R \& Hostetler, S. W. (2013). USGS National Climate Change Viewer. US Geological Survey. Retrieved from http:// www.usgs.gov/climate_landuse/clu_rd/nccv.asp
12. 从校舍峰的火灾瞭望台 远眺位于北加州的巴尔 德山。里昂牧场文化 景观的重要特征与系 统结构在这里清晰可 见，包括其历史悠久的 道路网络、畜牧场、俄 勒冈州白栋 (Quercus garryana) 林区和山地 草原。

12. Northern California's Bald Hills as seen from the Schoolhouse Peak fire lookout. Several significant features and systems of the Lyons Ranches cultural landscape are visible here, including the ranches' historic road network, stockyards, Oregon white oak Quercus garryanal habitat, and upland prairies.

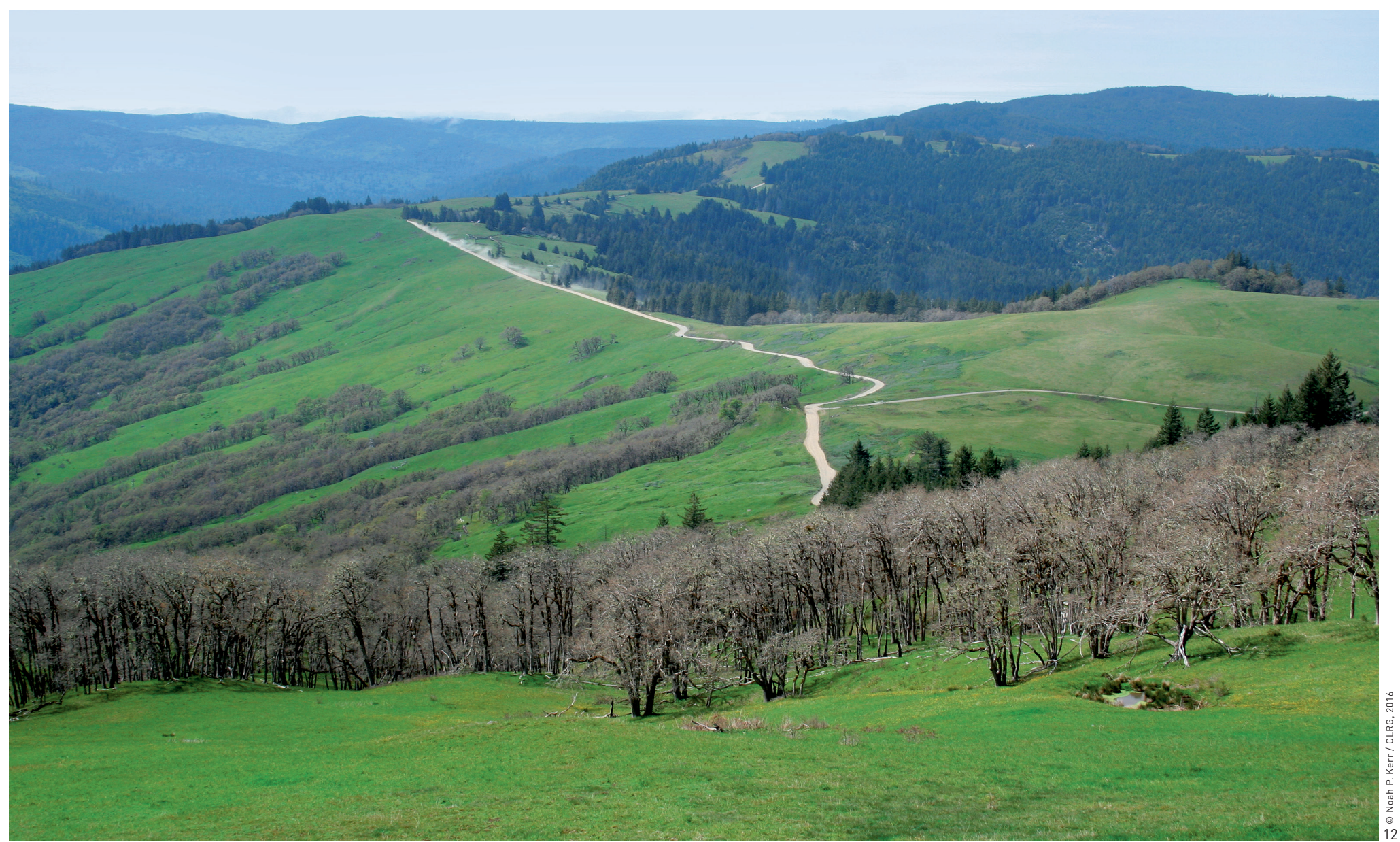

